\title{
QUEENSHIP, NUNNERIES AND ROYAL WIDOWHOOD IN CAROLINGIAN
}

\section{EUROPE}

Sometime during the last decade of the ninth century, Archbishop Fulk of Rheims composed a harshly-worded letter of admonition to the former empress Richildis, the second wife of the late Carolingian ruler Charles the Bald (843-77). ${ }^{1}$ The archbishop had heard some worrying stories concerning her lifestyle, and felt it incumbent upon him to warn her against the damage she was doing to her chances of eternal life by surrounding herself with associates engaged in 'anger, brawling, dissensions, burnings, murders, debauchery, dispossession of the poor and plundering of churches.' He urged her instead to show consideration for the health of her soul by living with piety and sobriety, and by performing good works to make up for the fact that virginity, the highest state to which a Christian woman could aspire, was now beyond her. ${ }^{2}$

We would be wrong to read this letter as representing the views of an impartial onlooker. There was not a black and white principle at stake: Fulk was hardly untarnished by the stain of 'brawling' and 'dissension' himself, as shown by his involvement in a particularly murky and violent factional struggle which ultimately led to his assassination. ${ }^{3}$ Moreover, from what we know about her later life, it is unlikely that Richildis was really behaving as

badly as he thought. ${ }^{4}$ The archbishop of Rheims was one of the most prominent of the churchmen of the Carolingian world who, sponsored by the ruling dynasty, had been engaged since the mid-eighth century in an earnest and ambitious project to reform society according to their interpretation of Christian principles. His blustery rhetoric was not reportage, but 
constituted a checklist of stereotyped accusations repeatedly imputed by Carolingian moralists to members of the lay aristocracy whose own standards of behaviour they sought to contain, influence and temper. ${ }^{5}$

Fulk's letter therefore introduces us to some central aspects of Carolingian thinking about the appropriate behaviour of laywomen especially, and serves as a way into the principal themes of this article. In particular, it is noticeable that the archbishop highlighted his expectations of Richildis in two roles: her supposed misdemeanour was concerned specifically with a failure to meet her obligations as a widow and as a queen. She had taken the 'veil of Christ' on her husband's death and ought to behave, said the archbishop, 'like a true queen, adorned with the virtues of her widowhood, holding before her eyes the day of death and resurrection.' According to the logic of Carolingian reform legislation, this meant that she should have retired to a nunnery. Carolingian prescriptive texts characterised widows as powerless people in need of protection, reflecting the reformers' patriarchal definition of lay morality and the right order of society. ${ }^{6}$ Attempts to restrict widows' choices were intensified during the reign of the emperor Louis the Pious (814-40), who, inspired by Biblical precepts, inaugurated systematic efforts to enforce on them monastic retirement and subjection to episcopal authority. ${ }^{7}$ In reality, the significance of widows as agents for the transmission of land and power meant that even if they took the veil they frequently remained, like Richildis, active in the secular world: lay society did not instantly transform itself in response to Carolingian pressure. ${ }^{8}$ Despite this, or more likely because of it, by the end of the ninth century this rhetoric was well developed, and Fulk was one of its most audible proponents. The didactic notion of widowhood as a distinct state with a particular set of 
qualities, rituals and codes of behaviour, what Fulk called 'the virtues of widowhood', filtered into diverse texts influenced by the Carolingian reforms, including poetry and hagiography. ${ }^{9}$

Whatever the nature of the now-obscure incident which triggered Fulk's diatribe (perhaps it was linked to both parties' high-profile interests in Lotharingia), it is thus significant that his response hinged on Richildis's failure to adhere to the stringent course of life set out by the church for widows: as far as the archbishop of Rheims was concerned, simply remaining uncloistered and continuing to participate in worldly affairs was what mattered. Yet this style of worldly widowhood (known by the term deo sacrata, referring to a woman who was veiled but not living in an enclosed community) was probably not unusual in the Carolingian world, despite the best efforts of the reformers. The problem was that Richildis was not just any widow: she was also a queen. As a queen and royal widow she had a special status which rendered her open to attack from her political enemies. ${ }^{10}$ The high profile of a queen made her conduct more visible and politically significant than that of most widows; and as we shall see, opponents like Fulk were able to draw on a ready-made discourse which was constructed to criticise queens in the ninth century. In the ninth century, rulers' morality was political. Consequently, Carolingian queens and empresses sometimes sought to avoid attacks of this nature and provide for their widowhood by founding nunneries, whose sacred aura provided a safer space for the exercise of political influence. The contexts in which they did so form the main focus of this article.

Carolingian queens always had particularly close relationships with monastic houses, as abbesses and lay proprietors. Historians have long recognised this. Yet the nature of these relationships, namely what queens actually did with their nunneries both as rulers and as widows, has not been fully explored. ${ }^{11}$ This article is intended to address some aspects of this 
lacuna. It will be argued that although the control of nunneries was always an important part of the role of female members of the royal family in the Carolingian realms, it became more closely associated specifically with queenship in the second half of the ninth century. This led queens of this period to found nunneries of their own, a novel trend which developed as a response to the increasingly intense criticisms levelled against royal consorts during the political crises of the 830s and 860s, and formed part of a gradual coalescence of ideas about the office of the queen in this period. However, although the growing importance of nunneries established by queens as forums for their founders' actions in the later ninth century was in part a defensive reaction to clerical attacks, these institutions could also provide platforms for enhancing the political power of the royal consort, and the royal widow. By acting as interfaces between the political centre and regional aristocracies, nunneries founded by queens became an integral part of the Carolingian political landscape.

Space will not permit anything like a full appreciation either of Carolingian queenship or female monasticism. Instead, by means of two case studies, our focus will rest fairly tightly on a few important aspects of queens' interaction with their convents in the later ninth century, and in particular on the reasons why reigning queens chose to found nunneries in the first place. The normally under-utilised charter evidence for these houses does, however, yield results which cast light back onto the conceptualisation and mechanics of queenship and royal widowhood more generally, and therefore helps us to contextualise more fully Fulk's attitude to Richildis. We must begin, however, by sketching out the evolving thought-world within which queenship was discussed in the ninth century. 
As the case of Richildis shows, even the exalted political position of an empress did not exempt her from the restrictive nature of Carolingian thinking on women's place in society. Indeed, far from being lifted above such considerations by virtue of their status, royal women were peculiarly vulnerable to attack in specific ways. The increasingly heavy pressure of Christian regulations contributed to the development of a gendered political language which was used to criticise queens during the ninth century. Queens were depicted as moral guarantors of the stability of the realm, and hence during political crises such as the rebellions against Louis the Pious in the 830s or the divorce case of King Lothar II (855- 69) they could be accused of sexual impropriety and of polluting the palace, which symbolised the kingdom. ${ }^{12}$ Such ideological characterisations are revealing less of the actual roles of queens in politics than of political relationships between men, namely kings and their principally male opponents. It was the fault of the ruler if his queen behaved immorally: in the wellknown phrase of the court intellectual Sedulius Scottus, the king's 'ministry' demanded control firstly of himself, then of his wife and children, and only thirdly of his subjects. ${ }^{13}$

Sedulius was writing for his patron Charles the Bald in the aftermath of, and partly in response to, Lothar's divorce case, the cause célèbre of the $860 \mathrm{~s} .{ }^{14}$ This protracted dispute revolved around the king's attempt, opposed by his uncles, to annul his barren marriage in favour of an earlier more informal union, and it helped to escalate the intensity of the church's strictures on lay morality and marriage in the context of debates about rulership.

Contemporaries reacted instantly to its implications. For example, in west Francia Charles the Bald (one of the uncles) responded to developments in Lothar's situation by establishing liturgical commemorations of his own marriage and by having his wife Ermentrude consecrated, in order to throw into focus the contrast between his own marital legitimacy and 
the dissolute behaviour of his nephew. ${ }^{15}$ Charles could hardly deploy the vocabulary of marital rectitude as a paradigm of order to attack Lothar without incorporating it into his own kingship. A precedent was set: the heat generated by the moral, theological and political debates of the 860s thus tightly fused together the vocabularies of kingship and of Christian marital propriety. ${ }^{16}$

Another outcome of these debates, to which we are introduced by the consecration of Ermentrude, was the rapid development of ideas about queenship. Earlier Carolingian rulers' wives had had no clearly defined 'formal' or 'official' role. ${ }^{17}$ They were certainly powerful, and clearly shared in their husbands' authority as consort, but the closest definitions of a queen's position in the first half of the ninth century ascribed her a role associated with the provisioning of the palace and its domestic aspects, symbolically and directly linked to the wider world. ${ }^{18}$ Beyond this, Carolingian thinkers tended to conceptualise queenship in terms of Biblical archetypes, exemplifying either virtue or evil. ${ }^{19}$ The imprecise concepts surrounding the position of queens were brought into sharper focus by the events of the $860 \mathrm{~s}$, and one result, namely the ceremonial composed for the consecration of Ermentrude, was the first in a series of Carolingian and Carolingian-influenced rituals for queenly anointings which, like those for kings, were anchored in the liturgy, and began to define a distinct office of queenship. ${ }^{20}$ This process of definition continued into the tenth century, during which queens in various kingdoms of Latin Europe enjoyed particularly prominent political roles.

In the course of the ninth century, then, and especially after the rebellions against Louis the Pious and the divorce of Lothar II, debates about kingship and the power of royal women were heavily informed by a wider gendered discourse about the position in society of lay women, married and widowed, and by the rhetoric of Christian marriage. ${ }^{21}$ The 
cumulative effect on the actual position of royal women was to define a set of parameters within which they were able to act: it is no accident that the process by which queens' power became more delineated coincided with an increase in the accusations of adultery and pollution levelled against them. ${ }^{22}$

Accusations made against royal women could also rebound on kings, as they had on Lothar II. The impact of these debates on the political life of the dynasty is indicated by the changing career paths of Carolingian princesses. ${ }^{23}$ The careful management of their daughters' marriages was essential for kings on a number of levels. Charlemagne's solution was to keep his numerous daughters at court, refusing to allow them to marry. Reacting to the implied scandal, and invoking standards of moral purity, his son and successor Louis the Pious immediately despatched these women (his sisters) to nunneries. ${ }^{24}$ However, it is the generation of Louis's children which yields the greatest evidence of the phenomenon of the royal abbess. Of the twenty-four ninth-century Carolingian kings' daughters whose fates can be ascertained after 840 , no fewer than eleven were monastic proprietors, despite the progressive marginalisation of female monasticism in the ninth-century church. ${ }^{25}$ Moreover, it is no coincidence that a high proportion of later ninth-century royal women retired to abbatial positions once their husbands were dead, probably under pressure from their fathers or other male relatives. ${ }^{26}$ Whereas widows in general often stayed in the world as deo $\underline{\text { sacratae }}$, the significance of royal widows rendered their choices more open to attack from political enemies. This evidence indicates a change in attitudes towards unmarried and widowed royal women prompted first by the debates about sexual morality at the court of Louis the Pious, and taken to a new level by the divorce case of Lothar II: in view of the pointed rhetoric of pollution and sexual impropriety which had been aired so volubly, it was 
inconceivable that a policy of keeping daughters out of wedlock or royal widows out of convents could be followed without rendering the king open to damaging criticism. Even Charlemagne's reputation did not survive untainted by retrospective rumours of unnatural sexual relations with his daughters. ${ }^{27}$

This increasing prominence in the ninth century of the royal female abbess or monastic proprietor was thus part of a reaction to developments in political debates in which female power was sometimes characterised as problematic and disruptive. As we shall see, this development was increasingly apparent in the careers of queens themselves, as well as in those of their daughters. Indeed, it became woven into the fabric of the office of queenship itself. Queenly control of nunneries brings together the themes of queenship, royal widowhood and political power. In order to examine these themes meaningfully, we must now locate them within the wider context of Carolingian monasticism and politics.

\section{II}

The management of monasteries was one of the fundamental bases of Carolingian power. It was in large part by appropriating control of massively wealthy and socially powerful abbeys in the eighth century that the dynasty was able to win over regional aristocratic networks and impose its nascent authority on the localities of the kingdom. ${ }^{28}$ Later, especially after the three-way division of the empire in 843 , the use of lay abbacies to reward faithful supporters was a key solution to the problem of restricted royal resources, and underwrote the efforts of fideles ('faithful men') to enforce royal commands. ${ }^{29}$ In addition, as major landholders, abbots and abbesses were responsible for providing a considerable proportion of the Carolingian army. Monasteries, especially those which benefited from royal 
immunities and protection and were thus involved in a particularly close relationship with the ruling house, were also foci for the Carolingians' less tangible but equally direct attempts at enhancing their dynastic charisma. Thus St-Denis outside Paris, Lorsch in the Rhineland and St-Ambrose in Milan served as kinds of mausoleums for various branches of the family, while the liturgical provisions made for their commemoration enabled 'distant rulers to make themselves present' throughout their extensive empire. ${ }^{30}$

These factors are even clearer when we look at the subset of monastic houses directly controlled by members of the dynasty, either as regular abbots/abbesses or as lay proprietors

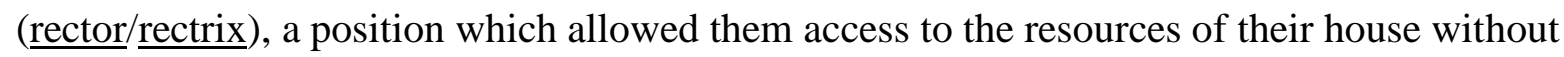
burdening them with liturgical duties or subjecting them to rules limiting their public activities. ${ }^{31}$ The distinctiveness of such houses has long been recognised, but their features have rarely been explored. ${ }^{32}$ Only a brief survey can be attempted here.

Some such monasteries were used for family management, to help keep the Carolingian family tree neatly pruned. Royal sons who were illegitimate and thus ineligible for kingship were usually compensated with possession of a royal monastery, although fullborn princes, who had expectations of power, could not be relegated in this way. ${ }^{33}$ Houses controlled by female members of the dynasty played a particularly important role in the fostering of Carolingian power. At the nunneries of Remiremont in Lotharingia and S. Giulia (also known as S. Salvatore) in Brescia, both controlled at times by various queens and princesses, the commemoration of members of the dynasty and their close fideles was undertaken on a large scale. ${ }^{34}$ At Chelles near Paris, meanwhile, the abbess Gisela, Charlemagne's sister, may have been entrusted with part of the imperial relic collection, and in 806 arguably supervised the composition of the Earlier Metz Annals, a triumphalist 
narrative celebrating the divinely-ordained rise of the Carolingians to kingship. ${ }^{35}$ These women thus worked to enhance Carolingian dynastic charisma, and hence to promote the idea that their political authority was proper and 'natural' ${ }^{36}$ This role within the family was probably linked to the wider involvement of aristocratic women in the memorialising of kin and ancestors. $^{37}$

More importantly for our purposes, such nunneries also served rulers as direct links into regional politics, allowing the dynasty to bypass other authorities. Thus, when Charles the Bald wanted to insert his daughter Rotrude as abbess of the important convent of the Holy Cross in Poitiers, he avoided the potential pitfalls of a canonical free election by sending three friendly bishops along to 'supervise'. Archbishop Hincmar of Rheims's letter of complaint about this procedure, from which we know the details of the case, implies that a faction within the abbey opposed the appointment of Rotrude, and had complained to him about the dice being loaded. ${ }^{38}$ In the early 870 s Hincmar protested again when Queen Richildis placed her own candidate in charge of the abbey of Origny (dép. Aisne). Charles the Bald supported his wife's actions, while the archbishop hurled accusations of simony at her for supposedly accepting bribes from the new incumbent. ${ }^{39}$ However, the key issue for Hincmar in both these cases was the brushing aside of 'correct' episcopal authority (i.e. his own) by rulers wishing to establish a direct connection to monastic institutions. In fact, royally-approved Carolingian reform rhetoric consistently promoted the episcopal subjection of nunneries in particular. ${ }^{40}$ The disputes over Poitiers and Origny demonstrate how even (or perhaps especially) monasteries with royal immunities and grants of free election were nonetheless subject to direct royal intervention which short-circuited the normal ecclesiastical hierarchy and plugged dynastic influence straight into a locality. ${ }^{41}$ 
The archbishop was exercised by similar concerns in 846 or early 847 in an exchange of letters centring on the nunnery of Avenay, just south of Rheims. He was accused by the Empress Irmingard, wife of Lothar I, of having had his men despoil the properties of the abbey, which was run by her daughter Bertha, a widow. He replied with what he probably hoped was disarming surprise and concern, and then wrote to Bertha herself complaining in no uncertain terms that in fact it was her people who had been making life difficult for his, by encroaching on the rights of the nearby monastery of Hautvillers, which pertained to Rheims. ${ }^{42}$ Whatever the precise details of the dispute, now lost, Bertha was clearly fulfilling her role in a very active fashion. There was a local political dimension to Hincmar's objections, as Rheims tradition held that Avenay had been given to the episcopal church in the seventh century by the family of the legendary founder of Hautvillers, Archbishop Nivardus. ${ }^{43}$ It is likely that the archbishops had indeed enjoyed control of the abbey until Bertha's arrival on the scene: certainly, Flodoard (our source) paraphrases Hincmar as saying rather pointedly that Rheims had only begun to suffer 'after that woman came to the kingdom. ${ }^{44}$ We can see here how the appearance of a royal scion in the neighbourhood could seriously upset the balance of regional power, bad news for those who, like Hincmar, had previously been able to dominate the locality.

The Avenay case also illustrates how the foundation and domination of religious houses could serve a strategic function, and demonstrates the responsiveness of these institutions to developments in high politics. ${ }^{45}$ The surrounding territory had been in the emperor Lothar's possession during the Carolingian family conflicts of $840-1$, and the abbey represented a focus for his efforts to maintain influence in the region. It is no accident that the quarrel sprang up at a time when there was bad blood between Charles the Bald, in whose 
kingdom the abbey lay, and Lothar, whose daughter was its abbess. Control of the convent and its resources was one of the points of conflict in this cold war: hence the exchange of letters between Lothar's wife Irmingard and Hincmar, about whom bad reports had apparently been made to the emperor; and hence the archbishop's cordial but pointed offer to get legates of the king (Charles) to adjudicate. It is also notable that after the tension between the two rulers was dissipated by the Treaty of Meersen in February/March 847, issued during an assembly at which Hincmar and Lothar also met for the first time, the Avenay dispute vanished. $^{46}$

Nunneries led by royal abbesses and rectrices therefore had an important role in negotiating the dynasty's influence in the regions of the empire. Moving beyond its mechanics, we also have some evidence for how this role was conceptualised. This evidence suggests that houses directly controlled by royal scions were perceived as a special group. Charles the Bald's Edict of Pitres (864) distinguishes 'the monasteries which we have granted and conceded to our wife, sons and daughters' from royal abbeys controlled by the king's close fideles. ${ }^{47}$ Although nunneries in this special category could be controlled by either queens or princesses, it also seems clear that queens were seen as having a specific position of influence over their daughters. Charles the Bald, in reference to his daughter Rothild, stated that her mother (Richildis) should make the decision as to whether she should marry or take the veil. ${ }^{48}$ The continuing influence of queens on their daughters and their convents is also suggested by the fact that, as we have seen, when Bertha first encountered trouble with Hincmar, it was her mother Irmingard who took the issue up with the archbishop. Moreover, when Hincmar aired his doubts about the election of the princess Rotrude to Holy Cross in 
Poitiers, he added that the leading clerics and vassals connected with the church should come to the queen, 'under whose protection they should stand after that of God and the saints., 49

We can go still further, as there are signs that queens' own control of abbeys was perceived as a particularly important component of their position as queens. ${ }^{50}$ The seventhcentury queen Balthild had been instrumental in establishing the association between the Merovingian dynasty and the supernatural power of the relics and priests housed in the kingdom's monasteries. This kind of queenly activity became part of Frankish political tradition as inherited and reshaped by the Carolingians, who actively fostered the cult of Balthild at her abbey of Chelles during the early decades of the ninth century, and saw to the production of a revised biography. ${ }^{51}$ In addition, it is no accident that one of the words habitually used to designate a queen, $\underline{\text { rectrix }}$, was also the word for the female proprietor of a convent; or that the earliest Carolingian ceremonies for the consecration of queens were based extremely closely on the rituals used for the inauguration of abbesses. ${ }^{52}$ Ideas associating queenship with leadership of nunneries were thus strong, and they began to take shape just as thinking about the role of queens more generally was becoming more defined. Historians have correctly stressed that the power of the king's wife rested in part on her capacity to produce male heirs. ${ }^{53}$ Yet the sonless Empress Engelberga remained a key power-broker in Italy for fifteen years after the death of her husband Louis II in $875{ }^{54}$ There was more to it than the mothering of future kings: as we shall see, Engelberga's spectacularly successful widowhood rested in large part on her control of monastic foundations.

Royal nunneries like Avenay or Poitiers were large-scale institutions, whose influence could engage the court with the political and social life of broad sections of the regional aristocracy, and which represented a type of monastic activity engaged in by royal women 
throughout the Carolingian period. However, if we turn now to the subset of houses actually founded by reigning Carolingian queens, we begin to deal with a group of houses which had unique characteristics, and which only appeared in the later ninth century. These were nunneries whose status reflected the strategic and political functions of the other royal monasteries we have been discussing, and which commanded similar sacred prestige, but whose influence concerned only the specific relationship between the dynasty and one aristocratic family: that of the queen herself. As opposed to the dynasties of late Anglo-Saxon England or the tenth-century continental kingdoms, whose princes were often married to daughters of foreign rulers, Carolingian heirs were always betrothed to members of regionally important high aristocratic families with whom political alliances were desired. These alliances often served short-term goals. However, it was in the interests of kings to maintain some sort of relationship with their wives' families, for the same political reasons as they had married in the first place. These relationships could be reactivated as and when they were needed. ${ }^{55}$

In this context, nunneries founded by kings' consorts on their family lands could bridge the gap between political centre and periphery in a very specific way, as the interface between the court and the resources of the queen's natal family. ${ }^{56}$ We have reasonable evidence for only five such institutions: a house established in Parma by Bernard of Italy's wife Cunigund in 835; Erstein in Alsace, founded by the empress Irmingard around 849; StScholastica, Juvigny, founded by Richildis in 874; a house known as S. Sisto in Piacenza, set up by the empress Engelberga in the same year; and finally the nunnery of Andlau in Alsace, founded by the empress Richgard during the 860s or 870s. ${ }^{57}$ Although few, their profile is nevertheless surprising enough in an age when nunneries were being edged out by large male 
monasteries. Moreover, while the founding of nunneries to anchor political identities was a consistent family strategy of the early medieval period, it is surely more than coincidence that we start to encounter these Carolingian royal institutions only in the aftermath of the scandals surrounding the wives of Louis the Pious and Lothar II.

If late-ninth century queenship and the control of nunneries went together, why did queens sometimes specifically choose to found their own houses, and what did they do with them? Two of these five abbeys furnish us with enough evidence to pursue in detail how the space between queens' royal and family identities could be filled by an abbatial role. They permit us to reflect further on queens' involvement in the regional dimensions of dynastic politics; and to identify the ways that queens' abbeys enabled them to maintain their power after the deaths of their husbands, despite the restrictive Carolingian ideologies which in effect served to limit the actions of royal women. As well as amplifying some of the general themes already discussed, these studies offer the rare opportunity to consider the consider Carolingian politics from queens' point of view.

III

Our first example, which highlights queenship in action, is Andlau in Alsace, founded by the empress Richgard, wife of Charles the Fat (876-88). In addition to this nunnery, by the end of 881 Richgard controlled the convents of Säckingen in Alemannia, SS Felix and Regula in Zurich and St-Marinus in Pavia, as well as the male monastery of Zurzach. ${ }^{58}$ These institutions were all placed in her hands in order to cement their special ties with the royal house. The landed power of some of these houses was formidable, while others had special strategic and economic significance. ${ }^{59}$ 
The empress's control of SS Felix and Regula in Zurich is worthy of note for more than simply the extent of its properties. The convent had been effectively founded by Charles's father Louis the German in 853 to intensify his influence in the south-west of his kingdom. ${ }^{60}$ The abbacy was held in turn by Louis' eldest daughter Hildegard until her death in 856 and then, after a short period when the incumbent was none other than Lothar II's infamous first wife Waldrada, Louis's youngest daughter, Bertha. ${ }^{61}$ Under Bertha the convent acquired royal immunity and protection in a charter of 863 co-signed by the abbess's brother, the young Charles the Fat. ${ }^{62}$ Its Carolingian credentials were thus impeccable.

To begin with, the nunnery's properties were focused in the immediate vicinity of Zurich, and were almost exclusively donations of the king and his family; the local nobility tended to patronise the nearby male foundations at Rheinau and St-Gall instead. However, the scope of the abbey's influence took a new turn when it acquired properties in Alsace in March 877 at the gift of its abbess Bertha. An examination of this gift provides some interesting insights. ${ }^{63}$ Bertha's grant was made only eight days before her death (d.26 March 877), and one of its conditions was that her brother Charles the Fat would issue a royal confirmation charter to enhance it. This he did, but not until March 878, a full year later. ${ }^{64}$ Why the delay? The answer seems to lie in the fact that Queen Richgard was not installed as proprietor of the abbey until February $878 .^{65}$ Charles was withholding his confirmation until his wife could be put in office, ensuring that the Alsatian possessions donated by Bertha would end up in her hands. ${ }^{66}$ The scale of these properties (twelve manses) was not especially impressive. However, an analysis of their history reveals that their political significance was greater than it may appear at first sight, and helps explain why the king was so keen that they should come into the control of his wife. 
The lands in question had been given to Bertha personally by Lothar II in 869 to thank her for assistance during his divorce case. ${ }^{67}$ They constituted estates at Sélestat (Schlettstadt), Kienzheim, Kinzheim, Altheim, Karsbach and Ammerschwihr, all in Alsace, and primarily in the northern half of that region. ${ }^{68}$ We know that at least three of these holdings had earlier been foci for the holdings of Erchangar, a prominent count based in northern Alsace who also happened to be the father of Richgard. ${ }^{69}$ He had received Kinzheim from Lothar I in 843, probably as the price for his support during the civil wars of that time, and subsequently used it as a base from which to expand his influence before his death in $865 / 6 .{ }^{70}$ In addition, we know from Lothar II's original gift to Bertha in 869 that the king dispossessed a certain 'Ercengarius puer [boy]', presumably the count's son, in order to make the grant of Sélestat and Ammerschwihr. We may further assume that the other goods held by Bertha were also originally in the hands of Erchangar's family. ${ }^{71}$ What the 869 grant to Bertha reveals, therefore, is a major political setback for Erchangar's family in the wake of his death, with Lothar taking advantage of the minority of the count's son to dispossess him and use his properties to curry favour with the family of Louis the German at a crucial point in his controversial divorce case. The fate of the family was then sealed in the aftermath of Lothar's death in August 869, when the count's nephew Bernard jumped the wrong way in the Carolingian scramble for the middle kingdom, unluckily for him backing Charles the Bald against the eventual ruler of Alsace, Louis the German. ${ }^{72}$

In other words, the Alsatian locations which the nunnery in Zurich received from the dying princess Bertha in 877 were properties with a longstanding connection to Richgard's immediate family, a connection which had been severed by Lothar II's diplomatic machinations at the end of the 860s. Richgard thus had a double claim on them, partly as 
family property, and partly as an element of the property subject to her as rectrix of the royal convent of SS Felix and Regula in Zurich, as it were ex officio. To put it another way, the properties represented a convergence of her formal (royal) and informal (family) jurisdictions. ${ }^{73}$ This explains why Charles delayed his confirmation of Bertha's deathbed bequest until Richgard was in charge of that institution: he was making absolutely sure that his wife would be the ultimate recipient and would make good this double claim, reasserting her control over properties which had earlier been dragged away from her family by the ebb and flow of dynastic politics, and thus reactivating its standing in northern Alsace. It is probable that he himself persuaded his sick sister Bertha to make the gift to the abbey with this very plan in mind. As we saw, his confirmation charter was issued at her request, and we do know of royal agents with close connections to the Zurich foundation under Bertha. ${ }^{74}$ The ways in which this 'double claim' was manifested in the politics of the reign of Charles the Fat are instructive. It is worth highlighting the fact that Richgard is not actually visible as active in Zurich itself at all: all the nunnery's business was carried out by advocates. ${ }^{75}$ Her attentions were focused instead at Andlau, the abbey in Alsace which she had founded on her own property sometime after her wedding in 861/2, and of which she became full-time abbess after retiring from the world in late $887 .{ }^{76}$ Here she took care to gather and preserve all the documents relating to the holdings of her family, and not just those concerning Andlau directly. ${ }^{77}$ It was hence Andlau which formed the focus for her commemoration of her family's control of its restored power base, including those parts of it which she commanded as rectrix of SS Felix and Regula in Zurich. However, it must be stressed that after 876 she ruled Andlau not purely as owner of an Eigenkloster (proprietary family monastery), but also as a queen and, after 881 , as empress. An imperial charter of 884 
indicates that the empress perceived clearly the coincidence of authorities invested in her position in Alsace. In this document, the emperor's man Otbert was granted holdings in the estate of Marlenheim for one lifetime, in recognition of the assiduousness of his obedience, after which the goods were to revert to Andlau. ${ }^{78}$ This estate had been in the possession of Richgard's father from the later 820s onwards; indeed, it seems to have been held corporately by his family, several of whom received a stake. ${ }^{79}$ In addition, it was the site of a royal residence used by both the Merovingians and the Carolingians. ${ }^{80}$ This charter therefore strengthens our appreciation of the political significance of the landholdings of Erchangar and his family in the region. More importantly, however, it reveals that Richgard's use of the monastery as a focus for the preservation of the memory of her family's rights and the reestablishment of its prominence in Alsace was coupled to a recognition of her husband's right to use it as a focus for the rewards of royal fideles. A second example, even more striking in this context, was the new palace which was constructed as the central focus for imperial authority in Alsace around 881 at Richgard's estate of Sélestat, once the property of her father, now belonging to her convent. ${ }^{81}$ Her family lands, pre-existing places of power in Alsace, were thus firmly clamped into royal structures. ${ }^{82}$ Richgard's family and royal identities converged on her abbey: here, at the point where the interests of the king meshed with the interests of his wife's family, we glimpse a practical example of late-ninth century queenship in action.

However, the success of Richgard in this region during the 880 s did not survive the death of her husband. After 888, her monastic empire began to fragment. In order to establish a bulwark in Alsace against the interests of King Rudolf of Burgundy, Charles's successor in the east Frankish kingdom, Arnulf, immediately installed a friendly count as 
proprietor of SS Felix and Regula in Zurich, depriving Richgard of the part of her family's Alsatian lands which were formally attached to that institution. ${ }^{83}$ Yet Richgard managed to ensure that her family's control of Andlau itself was perpetuated by a succession of abbesses from her kin. ${ }^{84}$ The community took to tampering with charters in an attempt to re-establish its hold over the lost Alsatian lands, while the nuns at Zurich produced a counter-forgery to close a documentary loophole in their own claim. ${ }^{85}$ Ultimately the abbey of SS Felix and Regula, backed by a series of royal patrons, won the day: Otto I confirmed its possession of the north Alsatian properties in $952 .^{86}$ The powerful family of Erchangar and Richgard, having been dispossessed once in the aftermath of the death of Lothar II, therefore lost out again after that of Charles the Fat. However, Andlau itself remained as a focus of their identity, enhanced by the burial there of Richgard after her death, probably in 906, and later by her canonisation in 1049 . The abbey was a foundation-stone of Charles the Fat's politics in Alsace, but it also sustained Richgard herself as queen, empress and widow. It was on this basis that it maintained its regional prominence into the high middle ages.

\section{IV}

Our second case-study takes us across the Alps, and allows us to see even more clearly the strategies which could be employed by a ruler's wife, in this case the empress Engelberga, spouse of Louis II of Italy (855-75), to maintain her position as a widow. ${ }^{87}$ Engelberga was a peculiarly prominent personality in manifold aspects of European politics between c.860 and her husband's death in 875 . She acted as Louis's regent, accompanied him on expansionary military campaigns in the south of the peninsula and represented him at diplomatic negotiations. ${ }^{88}$ Strikingly, she was also the beneficiary of a spectacular collection of charters. 
Almost one in seven of Louis II's extant charters were issued in her favour. ${ }^{89}$ Engelberga's conspicuous exploits in the field of charter acquisition did not diminish after the emperor's death, and this helped her to maintain a position as a key power-broker in Italian politicscontrol of land being a fundamental building-block of power in this period. ${ }^{90}$ In the interregnum following 875, during which Charles the Bald of west Francia and Karlmann of Bavaria fought to claim the succession to the heirless Louis, Engelberga herself conducted the negotiations and decided the loyalty of a major sector of the Lombard political community. ${ }^{91}$ She maintained this high profile until her death in 891.

One important foundation of her power was her control of the most important royal abbey of the Italian kingdom, the nunnery of S. Giulia (or S. Salvatore) in Brescia, which her husband granted her in 868 after the death of their daughter Gisela, the previous proprietor. ${ }^{92}$ This house was traditionally controlled by female members of the royal family, and it functioned as a focal point for the realm where kings, their families and their followers were commemorated together, providing a spiritual dimension to the political alliances which underpinned the realm. ${ }^{93}$ After 875 Engelberga retained control of S. Giulia, meaning that, unusually, it passed outside the immediate family circle of the ruling king. The city of Brescia was very much a focus of her family's power throughout the ninth century, and S. Giulia was a place with which her relatives had strong connections. ${ }^{94}$ The position of the family, known to historians and contemporaries as the Supponids, was further enhanced in that the next three rulers of Italy and their heirs were all married before their accession: there was no possibility of their marrying into another Italian lineage which could thus threaten the unique Königsnähe (nearness to the king) of Engelberga's kin. ${ }^{95}$ She thus retained a level of 
prestige similar to that which she had enjoyed while her husband lived, and more prominent than that normally accorded to widowed queens, especially those without sons.

Engelberga's defence of her power was cemented in 874 by the foundation of her own nunnery, S. Sisto in Piacenza. Three years later, in her 'testament', she gave this house most of the numerous fiscal properties which she had received over the years from her husband and his successors. ${ }^{96}$ The imperial, or 'official', nature of the foundation was further highlighted by the approval given to the project by Louis II, whose concern to secure his wife's future, and perhaps suspecting his death was at hand, led him to issue a charter granting her free disposal of all the royal lands she had accumulated. ${ }^{97}$ The document also signalled the apostolic approval bestowed by the pope, who 'adopted' Engelberga at Louis's instigation, also in 874 . The fact that the testament in favour of S. Sisto was enacted in a ceremony within the precincts of S. Giulia indicates that Engelberga perceived her position to be tied to the twin poles of her two major nunneries. ${ }^{98}$

However, the newly-endowed family house of S. Sisto and not the larger imperial institution of S. Giulia emerged as the mainstay of Engelberga's influence. Here most of the documents connected with her holdings and entourage were stored, including those relating to S. Giulia. ${ }^{99}$ This was made possible by the fact that, as well as its Carolingian connections, S. Sisto also had a strong Supponid identity, whose significance for her outweighed even the imperial aura of Brescia. Her testament was underwritten by an impressive array of nobles drawn from the ranks of royal officials and supporters, but also by all her brothers and other members of her extended family. Indeed, the text stated explicitly that she had acted 'with the agreement of my family and relatives. ${ }^{100}$ Among these relatives was her cousin Count Suppo III, here willingly underwriting a document which confirmed S. Sisto in possession of 
important estates which had been given to him by Louis II in $870 .{ }^{101}$ The corporate Supponid character of the new abbey, which may have made Suppo comfortable with entrusting his property to its control, is also suggested by its location in Piacenza. This city lay firmly within the family's sphere of influence, especially after Engelberga's brother married the daughter of the local count. ${ }^{102}$ By 880 , the incumbent count was the empress's nephew. ${ }^{103}$

The first abbess set over the forty nuns was the empress's sister Cunigund, and the testament specified that future leaders of the convent were to be members of the family, starting with Engelberga's daughter Irmingard: subsequent charters show that this family connection was in fact maintained. ${ }^{104}$ The necessary liturgical provisions for the nuns were to be organised by Bishop Paul of Piacenza, who was also a nephew of the empress. ${ }^{105}$ The nature of the commemorations which Engelberga requested in her will from these nuns and priests is also revealing: she demanded regular prayers not only for herself and for Louis II, 'but also for our own relatives, in commune.' The fact that S. Sisto was thus to serve as a focus for the memory and spiritual health of the Supponid family as well as for that of the Carolingians reveals Engelberga's concern to draw her whole family into a close relationship with the ruling dynasty, and to enshrine and perpetuate the close ties between them which she herself personified. ${ }^{106} \mathrm{~S}$. Sisto bridged the gap between her family and queenly identities. The dual planes on which the new foundation existed exemplify the aspirations and power of the Supponids, and they served to underpin Engelberga's own prominent political activities as a widow.

To illustrate these activities, we can also see how S. Sisto became the pivot of Engelberga's relationship with the new kings of Italy after 875 . Most striking was the gift made in 883 by Charles the Fat (king of Italy since 879 ) of the monastery of S. Maria at 
Masino on the west side of Lake Maggiore to his archchancellor Liutward. ${ }^{107}$ In 877 this abbey, owned by the empress, had become part of the patrimony of S. Sisto, and Charles himself had confirmed this state of affairs in $882 .{ }^{108}$ Engelberga's links to this church were close even before 870 , perhaps based on family ties. ${ }^{109}$ In her testament of 877 , moreover, Engelberga provided for the upkeep of ten monks at S. Maria who were to pray for her soul and that of her husband. ${ }^{110}$ The context of the empress's strong ties to the monastery, which was obviously of considerable importance, suggests that she must have consented to the decision to make the grant to Liutward, as does the fact that it seems to have come back into her possession after the archchancellor's disgrace in $887 .{ }^{111}$ Charles the Fat was evidently able to collaborate with Engelberga in the manipulation of her stock of fiscal properties, and hence to enhance the possibilities of royal patronage, in a similar manner to that which he had employed in Alsace with his own wife. Even fiscal properties which had been 'given away' thus remained potentially politically useful. Kings like Charles needed to maintain such relationships with the former empress, whose influence they required to render their own rule effective. Following other links between Charles and Engelberga also leads us back to S. Sisto. For instance, a document from 885 reveals that her advocate Adelbert, who represented the interests of S. Sisto, was also an imperial notary and legate. ${ }^{112}$ Engelberga's political eminence after her husband's death rested on such alliances with kings, built up and maintained by manipulating the material and political resources invested in her nunnery in Piacenza. $^{113}$

As empress, Engelberga's power rested on a number of bases, beyond the informal influence she wielded as imperial consort: these were her control of S. Giulia, the prodigious generosity of her husband and her family's presence in the cities of Brescia and Piacenza. 
After Louis II's death, however, all these strands were fused together in the single focus of S. Sisto, enabling her to avoid the sudden plummet in social status which widowhood (even royal widowhood) could entail. ${ }^{114}$ The same fiscal estates which had been hers as empress were built into the endowment of the new house and thus tied into a permanent relationship with her family, who were commemorated there alongside the late emperor. As a monastic proprietor, she was able to draw together her family power and royal status. ${ }^{115}$ Although after her husband's demise in 875 she became a holy widow, deo sacrata, Engelberga did not

retreat from the political world. ${ }^{116}$ By remaining in the world she entered what was probably a common form of religious widowhood in the Carolingian period. However, as a prominent royal widow in the post-Lothar II era she was, like Richildis, peculiarly open to attack from powerful opponents wielding the reformers' rhetoric of morality and propriety. As such, by channelling her existing political resources through an abbey, she cut some of the ground from under the feet of potential enemies, and at the same time effectively crystallised and perpetuated the power she had wielded while her husband lived.

\section{$\mathrm{V}$}

The nunneries we have been discussing were like airlocks connecting the formal and informal spheres of queenly activity. They acted as foci of royal patronage, served as points of contact between royal and aristocratic power and, just like other dynastic monasteries, disposed of lands which were used in the execution of royal politics. At the same time, however, they were centres of identity and power for the families of the queens and, even more importantly, for the queens themselves in anticipation of their widowhood. This interaction between queens' family and 'official' roles was not novel: Carolingian kings' 
wives were always a fulcrum linking natal and royal resources. For example, it may have been under the influence of his fourth wife Fastrada, whose family had interests in the region, that Charlemagne chose to develop his eastern palace at Frankfurt, a decision which echoes the context for the construction of Sélestat in Alsace in $881{ }^{117}$ However, the articulation of this kind of queenly influence through the control of monastic institutions seems only to have taken off in the second half of the ninth century, when thinking about the moral role of queenship had been given a new urgency by the controversies surrounding Louis the Pious and Lothar II. Nunneries conferred on queens a stake in sacred power, a sanctified space within which to praise God, and also to pursue family agendas. ${ }^{118}$ An abbatial role in a sense sanctified and even liturgified the position of the queen or royal widow by extension: the intertwining of temporal and sacred power within the walls of monastic foundations was what made them so suitable for this kind of activity, and helped shield their proprietors from critiques of moral conduct. This was one crucial aspect of queenly power in the particular circumstances of the later ninth century. Carolingian queens were more vulnerable to attack than their aristocratic cousins, and must have very been aware of the restrictions on widows' positions, especially their subjection to episcopal authority. It is therefore no accident that both Andlau and S. Sisto were carefully and publicly approved by the pope, the ultimate bishop. Nor is it a coincidence that the clearest examples of such strategies come from the middle kingdom. This realm was the most disputed area of the Carolingian Empire, and changed hands frequently: for this reason, its aristocratic power-brokers were engaged in a constantly evolving series of manoeuvres to maintain their positions.

As we have seen, other queens embarked on similar, if more evidentially opaque, projects. Cunigund, widowed by the death of her husband King Bernard of Italy in 818 , 
founded a convent in Parma to control her properties in 835. After being so long a widow, it is worthy of note that she acted thus in the wake of the rebellions against Louis the Pious, during which legislation limiting the activities of widows had been sharpened as part of the frank exchange of views about sexual morality. Her foundation was a success, and her resources remained in the control of the community and of her family for at least a century. ${ }^{119}$ Erstein in Alsace was founded for similar purposes by the Empress Irmingard around the year 849 and richly provisioned with relics of martyrs and popes. ${ }^{120}$ However, we should not think of this kind of monastic activity as having become an 'institution' of queenship, or of royal widowhood. Although she was an ex-empress and a highly influential figure, Engelberga was regarded by kings not as a special kind of widow or abbess, but rather as 'sister', using the generic familial idiom in which Carolingian politics was habitually articulated. ${ }^{121}$

Moreover, there were other possible choices. One was remarriage: several widowed royal women contracted extremely successful second marriages. ${ }^{122}$ Another is highlighted by the case of Richildis, with which we began. In 874 she founded a nunnery on her family land at Juvigny near Stenay on the Meuse, acquiring relics of St. Scholastica as a patron. ${ }^{123}$ This foundation may have been intended to serve a similar purpose to Andlau and S. Sisto. However, the part of the middle kingdom in which it lay did not remain central to the ambitions of Richildis's husband Charles the Bald for long, and the abbey seems to have quickly fallen on hard times. Already in 877, Richildis's brother Boso can be found intervening with the king to have parts of the estate of Juvigny, in which he evidently also had a stake, granted to the monastery of SS Frobert and Peter near Toul. ${ }^{124}$ Thereafter, the house does not resurface in the sources until its restoration in the eleventh century. ${ }^{125}$ However, we meet Richildis again in two charters of the year 910, in which she is found giving some of her 
lands to the prominent male monastery of Gorze in exchange for receiving them back, along with several more, as a life interest. ${ }^{126}$ Some of these properties were among the most significant in the region. ${ }^{127}$ More importantly, however, this was an area in which her family had a strong presence. Richildis's father Bivin was lay abbot of Gorze between 855 and 863, and had taken steps to ensure that his children retained interests in the monastery's lands. ${ }^{128}$ It seems clear that Richildis made a deliberate choice to fall back in her widowhood not on her own foundation of Juvigny, but rather on one of her family's older power-bases, by reactivating her links with Gorze. ${ }^{129}$

This alternative path, however, left her unprotected when she clashed with Archbishop Fulk. In essence, Richildis was not doing very much different from her contemporaries Richgard and Engelberga in attempting to maintain her position by building up control over lands traditionally held by her family. The differences were of circumstance and style rather than substance: unlike Richgard and Engelberga, whose secular influenced was wielded as a function of their roles as monastic proprietors, the context of Richildis's political activities was unambiguously worldly. As noted, in reality hers was not an exceptional model of ninthcentury widowhood. However, in the rhetorical climate of the era after Lothar II's divorce, if a prominent figure like a widowed empress acquired an enemy like an archbishop of Rheims, this was not a state of affairs likely to go unmentioned. Female Carolingians were vulnerable to such accusations of worldly sin, and were liable to be attacked using the prefabricated language developed in the ninth century to critique the moral conduct of powerful women. By extension, the kings to whom they were related were also vulnerable, as Lothar II had been. Recognition of this situation must have been a factor in the decisions of Richgard and Engelberga (in association with their husbands) to focus their interests on the abbeys they 
founded. They made a virtue of the necessity of having to operate within the constricting patriarchal rhetoric laid down by the male thinkers of the Carolingian world, and managed to recast their political influence in a new mould.

In doing so, they contributed to the development of ideas and practices surrounding the role of queenship. ${ }^{130}$ The increasing association of the role of abbess/rectrix with that of queen was an important development of later ninth-century political culture. Furthermore, the control of abbeys became a characteristic feature of the more institutionalised forms of queenship which developed in the Carolingian successor kingdoms of the tenth century. Tenth-century queens' increasingly formal positions drew more on roles such as regency and the care of dynastic commemoration than on their relationship with their kin: as many were foreigners, their role was different by definition. ${ }^{131}$ In keeping with this, Ottonian queens, rather than establishing monasteries which served their natal families' interests, were involved in the founding of houses on crown lands which were dedicated to the benefit of the dynasty (into which they had married) as a whole. ${ }^{132}$ They, like their west Frankish and Anglo-Saxon counterparts, usually controlled the same estates and religious houses in turn, as a kind of $\underline{\text { ex }}$ officio adjunct to their position. ${ }^{133}$ These developments in the institutions and conceptions of queenship were mirrored by a closer definition of what it meant to be a royal widow. Whereas ninth-century authors like Fulk were beginning to grasp towards a coherent conception of royal widowhood, texts written for tenth- and early-eleventh century queens such as the Second Life of the Empress Matilda or the Life of Clotild, building on ideas developed by Carolingian moralists, delineated a clearer life progression for the queen as wife and widow. Even in widowhood, the idea was promoted that royal women should continue to serve their husband's memory, almost as a continuation of marriage. ${ }^{134}$ The sometimes 
problematic position of queens and royal widows in the ninth century was thus resolved in the tenth, when a more fixed role was found for them within the apparatus of the Ottonian, west Frankish and west Saxon dynasties. This role was still often articulated through control of nunneries: but these represented a fuller integration of dynastic female foundations into the political system, as family convents like Andlau and S. Sisto became increasingly marginalised by the logic of the Carolingian and tenth-century church reforms. ${ }^{135}$

Nevertheless, the subtly altered structures of the tenth century were built on the inheritance of the specifically 'monastic style' of queenship and royal widowhood supported by houses like Andlau and S. Sisto. ${ }^{136}$ The transgressions of gender and status of which Fulk thought Richildis guilty were nimbly sidestepped by Richgard and Engelberga in their capacity as royal abbesses and holy widows. Their tenth-century successors, however, married into a political system which had been adapted to contain the dangers of such social contamination, and which consequently cleared a greater formal space for the exercise of queenship and royal widowhood within the walls of dynastic nunneries.

The contingent strategies employed by the empresses of the later ninth century to protect themselves from the pitfalls of widowhood by focusing their resources on the nunneries they founded were a practical aspect of the notions of queenship which were developing from the mid-ninth century onwards. The key position of abbeys in the more sophisticated framework of tenth-century queenship reached directly back to foundations like Andlau and S. Sisto. Nevertheless, the specific role played by individual houses in the power of queens peaked in the tenth century. With the eleventh century the phenomenon of the powerful aristocratic or royal widow commanding a network of alliances and properties from within the cloisters was replaced by the widow who lived in the world, a friend of the Church 
rather than a dominator of churches. ${ }^{137}$ Richgard and Engelberga were improvisers, making the best of contemporary restrictions imposed on them as rulers' wives and widows; Richildis, on the other hand, may have been ahead of her time.

$\underline{\text { University of St Andrews }}$

$\underline{\text { Simon MacLean }}$ 
$1 \quad$ I am very grateful to Matthew Innes, Claire Jones, Janet Nelson and Julia Smith for detailed comments and criticisms. I would like to thank the participants at seminars in Cambridge, Liverpool and London at which earlier versions of this paper were read. I also thank Stuart Airlie and Cristina La Rocca for sending me copies of their unpublished work, and Francesca Tinti for helping me acquire an elusive source.

2 Flodoard, Historia Remensis Ecclesia, iv. 5 (eds. I. Heller and G. Waitz, Monumenta Germaniae Historica [hereafter MGH], Scriptores xiii, Hanover, 1881, 566-7). Fulk was archbishop from 883 until 900 and the letter is undated, but it is surrounded by others from the 890 s.

3 G. Schneider, Erzbischof Fulco von Reims (883-900) und das Frankenreich (Munich, 1973).

$4 \quad$ See below at n.123 for Richildis's later life.

5 See Janet L. Nelson, 'Women and the Word in the Earlier Middle Ages', Studies in Church History, xxvii (1990); Julia M.H. Smith, 'Gender and Ideology in the Early Middle Ages', Studies in Church History, xxxiv (1998); see also Pauline Stafford, 'The Portrayal of Royal Women in England, mid-Tenth to mid-Twelfth Centuries', in J. Carmi Parsons (ed.), Medieval Queenship (Stroud, 1994).

6 MGH Capitularia regum Francorum, 2 vols. (eds. A. Boretius and V. Krause, Hanover, 1893-7), i, no.33, c.5, p. 93; ii, no.196, c.53, p. 47 is another explicit statement. The appearance of such items near the head of capitularies, if not always in chapter 1, is typical. The issue was also tied up with Carolingian attempts to regulate marriage rites: in particular, remarriage was still controversial. See Pierre Toubert, 'La Théorie du marriage chez les moralistes carolingiens', Settimane di Studi sull' alto medioevo, xxiv (1977); Pierre Toubert, 'The Carolingian Moment (Eighth-Tenth Century)', in A. Burguière et al (eds.), A History of the Family (Cambridge, 1996); J. Gaudemet, Le Marriage en occident. Les moeurs et le droit (Paris, 1987), 109-32. For a 
longer perspective see J. McNamara and S.F. Wemple, 'Marriage and Divorce in the Frankish Kingdom', in S.M. Stuard (ed.), Women in Medieval Society (Pennsylvania, 1976).

7 See MGH Capit. ii (eds. Boretius and Krause), no.196, cc.47-51, p. 42; c.51 quotes 1 Tim 5,6: 'The widow who lives extravagantly is dead while she lives.' See Janet L. Nelson, 'The Wary Widow', in Wendy Davies and Paul Fouracre (eds.), Property and Power in the Early Middle Ages (Cambridge, 1995), esp. 89-92; B.-M. Tock, 'L'Image des veuves dans la literature médiolatine belge du VIIIe au XIIe siècle', in Michel Parisse (ed.), Veuves et veuvage dans le haut moyen age (Paris, 1993), esp. 39-42; Patrick Corbet, 'Pro anima sua. La pastorale ottonienne du veuvage', in Parisse (ed.), Veuves, 241.

$8 \quad$ Nelson, 'Wary Widow', passim.


Sanctorum, May 12, col.78-98, represents the zenith of these themes in Carolingian hagiography: see Julia M.H. Smith, 'The Hagiography of Hucbald of St-Amand', Studi Medievali, xxxv (1994); Julia M.H. Smith, 'The Problem of Female Sanctity in Carolingian Europe, c.780-920', Past and Present, cxlvi (1995); K. Heene, 'Merovingian and Carolingian Hagiography: Continuity or Change in Public and Aims?', Analecta Bollandiana, cvii (1989). Three contributions to Parisse (ed.), Veuves are relevant here: E. Palazzo, 'Les formules de bénédiction et de consécration des veuves au cours du haut moyen âge’; Michel Parisse, 'Des veuves au monastère'; Régine Le Jan, 'Aux origines du douaire médiéval (VIe-Xe siècles)’. Cf. Julia Crick, 'Men, Women and Widows: Widowhood in Pre-Conquest England', in S. Cavallo and L. Warner (eds.), Widowhood in Medieval and Early Modern Europe (Harlow, 1999).

10 On the interaction of class and gender, see Nelson, 'Women and the Word', esp. 63; Guy Halsall, 'Female Status and Female Power in Early Medieval Central Austrasia: the Burial Evidence', Early Medieval Europe, v (1996), esp. 24. Note that in the context of the present article queens and empresses should not be thought of as qualitatively distinct. 
11 I am grateful to Dr Stuart Airlie for showing me part of his forthcoming book Carolingian Politics, which will also address these issues.

12 Elizabeth Ward, 'Agobard of Lyons and Paschasius Radbertus as Critics of the Empress Judith’, Studies in Chruch History, xxvii (1990); Stuart Airlie, 'Private Bodies and the Body Politic in the Divorce Case of Lothar II', Past and Present, clxi (1998); Stuart Airlie, 'The Palace of Memory: the Carolingian Court as Political Centre', in S. Rees Jones, R. Marks and A.J. Minnis (eds.), Courts and Regions in Medieval Europe (York, 2000).

13 Sedulius Scottus, Liber de rectoribus christianis, c.5 (ed. J.P. Migne, Patrologia Latina, ciii, col.300). These ideas had roots in a wider discourse about women's role in the household: Smith, 'Gender and Ideology', $64-71$.

14 N. Staubach, Rex christianus: Hofkultur und Herrschaftspropaganda im Reich Karls des Kahlen. Teil II (Cologne, Weimar and Vienna, 1993), 105-12; Airlie, 'Private Bodies'.

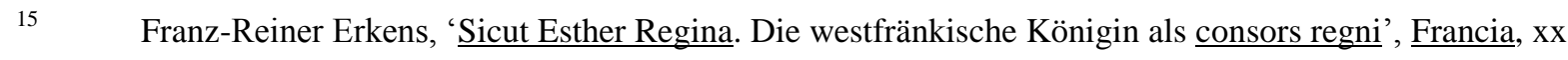
(1993), 35-6.

16 K. Heidecker, 'Why Should Bishops be Involved in Marital Affairs? Hincmar of Rheims on the Divorce of King Lothar II (855-869)', in J. Hill and M. Swan (eds.), The Community, the Family and the Saint. Patterns of Power in Early Medieval Europe (Turnhout, 1998), esp. 233.

17 Cristina La Rocca, 'La Reine et ses liens avec les monastères dans le royaume d'Italie', in Régine Le Jan (ed.), La Royauté et les elites dans l'Europe carolingienne (début IXe siècle aux environs de 920) (Lille, 1998), 269-70; Erkens, 'Esther', 17. 
18 MGH Capit. i (eds. Boretius and Krause) no.42; Agobard, Libri duo pro filiis, c.2.2 (ed. G. Waitz, MGH Scriptores 15, p. 277); Hincmar, De Ordine Palatii, c.22 (eds. T. Gross and R. Schieffer, MGH Fontes 3 , Hanover, 1980, 72-4). See Elizabeth Ward, 'Caesar's Wife: the Career of the Empress Judith, 819-29', in Peter Godman and Roger Collins (eds.), Charlemagne's Heir: New Perspectives on the Reign of Louis the Pious (81440) (Oxford, 1990), 206-7. On queens' acivities in general see J. Hyam, 'Ermentrude and Richildis', in M. Gibson and J.L. Nelson (eds.), Charles the Bald. Court and Kingdom, $2^{\text {nd }}$ ed. (Aldershot, 1990); Hans-Werner Goetz, 'Frauenbild und weibliche Lebensgestaltung im fränkischen Reich', in Hans-Werner Goetz (ed.), Weibliche Lebensgestaltung im frühen Mittelalter (Cologne, Weimar and Vienna, 1991), 23-9.

19 Geneviève Bührer-Thierry, 'La Reine adultère', Cahiers de civilisation médiévale Xe-XIIe siècles, xxxv (1992); Mayke de Jong, 'Exegesis for an Empress', in Mayke de Jong and Esther Cohen (eds.), Medieval

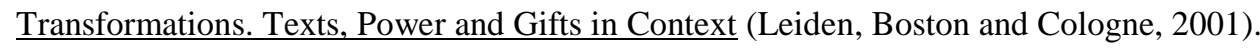

20 Assuming the 856 Judith ordo is categorised as Anglo-Saxon: see Janet L. Nelson, 'Early Medieval Rites of Queen-Making and the Shaping of Medieval Queenship', in Anne J. Duggan (ed.), Queens and Queenship in Medieval Europe (Woodbridge, 1997); reprinted in Janet L. Nelson, Rulers and Ruling Families in Early Medieval Europe: Alfred, Charles the Bald and Others (Aldershot, 1999).

21 Nelson, 'Women and the Word'; Smith, 'Gender and Ideology'. See also Katrien Heene, The Legacy of Paradise. Marriage, Motherhood and Woman in Carolingian Edifying Literature (Frankfurt, 1997).

22 Bührer-Thierry, 'La Reine adultère'. Cf. Pauline Stafford, Queen Emma and Queen Edith. Queenship and Women's Power in Eleventh-Century England (Oxford, 1997), 67-8.

23 The following paragraph is intended to be illustrative of a general point: the analysis of deeper patterns within Carolingian female monasticism and their relationship to family politics awaits further research. Rudolf Schieffer, 'Karolingische Töchter', in G. Jenal (ed.), Herrschaft, Kirche, Kultur. Beiträge zur Geschichte des 
Mittelalters. Festschrift für Friedrich Prinz zu seinem 65. Geburtstag (Stuttgart, 1993) also indicates the significance of c.840 as a turning point.

24 Janet L. Nelson, 'Women at the Court of Charlemagne: A Case of Monstrous Regiment?', in Janet L. Nelson, The Frankish World, 750-900 (London and Rio Grande, 1995), 237-41.

25 Silvia Konecny, Die Frauen des karolingischen Königshauses. Die politische Bedeutung der Ehe und die Stellung der Frau in der fränkischen Herrscherfamilie vom 7. bis zum 10. Jahrhundert (Vienna, 1976), 1501; based on Karl Voigt, Die karolingische Klosterpolitik und der Niedergang des westfränkischen Königtums. Laienäbte und Klosterinhaber (Stuttgart, 1917), 39-43 and Karl Ferdinand Werner, 'Die Nachkommen Karls des Großen bis um das Jahr 1000 (1.-8. Generation)', in W. Braunfels (ed.), Karl der Grosse. Lebenswerk und Nachleben, 5 vols., (Dusseldorf, 1965-7), iv, 449. Cf. Eugen Ewig, 'Descriptio Franciae', in E. Ewig, Spätantikes und fränkisches Gallien, 2 vols., (Munich, 1976), i, 304 with nn.125-6. On the relative numbers and status of female foundations see J.T. Schulenberg, 'Women's Monastic Communities, 500-1100: Patterns of Expansion and Decline', Signs, xiv (1989); A. Veronese, 'Monasteri femminili in Italia settentrionale nell'alto mdioevo', Benedictina, xxxiv (1987); and especially Jane Martindale, 'The Nun Immena and the Foundation of the Abbey of Beaulieu: a Woman's Prospects in the Carolingian Church', Studies in Church History, xxvii (1990); cf. D. Baltrusch-Schneider, 'Klosterleben als alternative Lebensform zur Ehe?’, in Goetz (ed.), Weibliche Lebensgestaltung, 47-50.

26 See Schieffer, 'Karolingische Töchter', 130-5 for details of the known cases.

27 Nelson, 'Regiment'; Paul Edward Dutton, The Politics of Dreaming in the Carolingian Empire (Lincoln and London, 1994), 50-80; Roger Collins, 'Charlemagne and his Critics, 814-829', in Le Jan (ed.), La Royauté. For the wider context see Schieffer, 'Karolingische Töchter'.

28 Matthew Innes, $\underline{\text { State and Society in the Early Middle Ages. The Middle Rhine Valley, 400-1000 }}$ (Cambridge, 2000). 
Janet L. Nelson, Charles the Bald (London and New York, 1992), 61-2.

Order', in R. Gameson and H. Leyser (eds.), Belief and Culture in the Middle Ages (Oxford, 2001), 100; Janet L. Nelson, 'Carolingian Royal Funerals', in Frans Theuws and Janet L. Nelson (eds.), Rituals of Power: from Late Antiquity to the Early Middle Ages (Leiden, Boston and Cologne, 2000); Eugen Ewig, 'Der Gebetsdienst der Kirchen in den Urkunden der späteren Karolinger', in H. Maurer and H. Patze (eds.), Festschrift für Berent

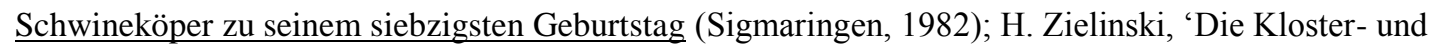
Kirchengründungen der Karolinger', in I. Crusius (ed.), Beiträge zu Geschichte und Struktur der mittelalterlichen Germania Sacra (Göttingen, 1989).

31 On this kind of division of labour see H. Becher, 'Das königliche Frauenkloster San Salvatore/Santa Giulia in Brescia im Spiegel seiner Memorialüberlieferung', Frühmittelalterliche Studien xvii (1983), 308-10. On abbesses' restrictions see J.T. Schulenberg, 'Strict Active Enclosure and its Effects on the Female Monastic Experience (500-1100)', in J.A. Nichols and L.T. Shank (eds.), Medieval Religious Women. Volume 1: Distant Echoes (Kalamazoo, 1984).

32 Other than case-studies, Voigt, Die karolingische Klosterpolitik, is still the only sustained survey; Franz J. Felten, Äbte und Laienäbte im Frankenreich. Studien zum Verhältnis von Staat und Kirche im frühen Mittelalter (Stuttgart, 1980), is thin on the later ninth century.

33 It should be acknowledged that the categories of 'royal' and 'proprietary' monasteries were not fixed in contemporary thought; yet they remain useful for the historian. See J. Bernhardt, Itinerant Kingship and Royal Monasteries in Germany, 919-1056 (Cambridge, 1994), 70-5. For the problems encountered by kings who tried to impose monastic careers on legitimate-born sons, see Nelson, Charles the Bald, 226-31. 
$34 \quad$ Liber Memorialis Romaricensis, (eds. E. Hlawitschka, K. Schmid and G. Tellenbach, MGH Libri Memoriales, i, Dublin and Zurich, 1970); M. Parisse (ed.), Remiremont: l'abbaye et la ville (Nancy, 1980); Becher, 'Frauenkloster'.

35 Janet L. Nelson, 'Gender and Genre in Women Historians of the Early Middle Ages', in Nelson, Frankish World, 191-4; Nelson, 'Regiment', 236.

36 Stuart Airlie, 'Semper fideles? Loyauté envers les carolingiens comme constituant de l'identité aristocratique' in Le Jan (ed.), La Royauté. Airlie, Carolingian Politics will demonstrate the crucial role of royal women in these structures.

37

Karl Leyser, Rule and Conflict in an Early Medieval Society: Ottonian Saxony (London, 1979), 49-73;

Patrick Geary, Phantoms of Remembrance. Memory and Oblivion at the End of the First Millennium (Princeton, 1994), 48-80; E.M. van Houts, Memory and Gender in Medieval Europe, 900-1200 (London, 1999).

38 Flodoard, $\underline{\text { Historia, }}$,iii. 27 (eds. Heller and Waitz, 548-9).

39 Flodoard, $\underline{\text { Historia, }}$,ii. 23, iii. 25, iii. 27 (eds. Heller and Waitz, 531, 538, 549-50). An episcopal vacancy in nearby Laon helped the queen: L. Duchesne, Fastes épiscopaux de l'ancienne Gaule, 3 vols. (Paris, 1915), iii, 140 .

40 Michel Sot, Un Historien et son église. Flodoard de Reims (Paris, 1993), 612-14 on Hincmar; on the legislation, see Schulenberg, 'Enclosure', 58-9. This was driven by concerns over moral purity: J. Verdon, 'Notes sur le role économique des monastères féminins en France dans la seconde moitié du IXe et au début du Xe siècle', Revue Mabillon, cclx (1975), 334.

41 Barbara H. Rosenwein, Negotiating Space. Power, Restraint and Privileges of Immunity in Early Medieval Europe (Manchester, 1999). 
Flodoard, Historia, iii. 27 (eds. Heller and Waitz, 547-8).

Flodoard, Historia, iii. 27, iv. 47 (eds. Heller and Waitz, 549, 595-6); Acta Sanctorum, April III, 622; May I, 113. Flodoard had specific reasons for wishing to re-emphasise this claim in the mid-tenth century: Sot, Un historien, 613.

44

Flodoard, Historia, iii. 27 (eds. Heller and Waitz, 548). Ibid., 549 shows that Hincmar was later closely involved in the running of the abbey once Queen Ermentrude had taken it over.

45 Hincmar's prominence in this discussion is not simply a trick of the evidential light: the diocese of Rheims, in the Carolingian heartlands, was one of the most densely packed with royal monasteries: Ewig, 'Descriptio', 306-7. For another 'strategic' example, Zurich, see below at nn.

46 Jean Devisse, Hincmar. Archevêque de Reims, 845-82, 3 vols. (Geneva, 1975), i, 37-8. For the wider political context see Rosamond McKitterick, The Frankish Kingdoms Under the Carolingians, 751-987 (London and New York, 1983), 174.

47 MGH Capit., ii (eds. Boretius and Krause), no. 273, c. 5, p. 313. Thomas Zotz, 'Grundlagen und Zentren der Königsherrschaft im deutschen Südwesten in karolingischer und ottonischer Zeit', in H. Nuber et al (eds.), Archäologie und Geschichte des ersten Jahrtausends in Südwestdeutschland (Sigmaringen, 1990), 283 shows how royal monasteries formed a distinct group which could act as a special focus for the gifts of the aristocracy.

48 MGH Capit., ii (eds. Boretius and Krause), no. 281, p. 355. This had particular resonance when it was proclaimed in 877 , a time when Charles was trying to curb the potential authority of his son. 
(1998), 24-7 discusses a telling example of the specific role played by queens in the relationship between the royal dynasty and its favoured monasteries.

$51 \quad$ Eugen Ewig, 'Das Privileg des Bischofs Berthefrid von Amiens für Corbie von 664 und die Klosterpolitik der Königin Balthild' in Ewig, Gallien, ii; Janet L. Nelson, 'Queens as Jezebels: the Careers of Brunhild and Balthild in Merovingian History' in D. Baker (ed.), Medieval Women (Oxford, 1978); Rosenwein, Negotiating Space, $78-83$.

$52 \quad$ Nelson, 'Rites', 309-10.

53 Pauline Stafford, 'Sons and Mothers: Family Politics in the Early Middle Ages', in Baker (ed.), Medieval Women, esp. 90-2.

54 C. Odegaard, 'The Empress Engelberge', Speculum, xxvi (1951).

55 Thus Die Urkunden Lothars I. und Lothars II. (ed. T. Schieffer, MGH Diplomata Karolinorum iii, Berlin, 1966), Lothar I no.27 contains a clause stating that it is fitting for emperors to listen to the claims of their 'coniuncti' (in-laws). This dates from 835, when the support of his father-in-law Hugh was particularly important to Lothar. Cf. nos. 23 and 29.

56 In this they complemented dowers, which were used to enhance the positions of queens' families:

Régine Le Jan, 'Douaires et pouvoirs des reines en France et en Germanie (VIe-Xe siècle)', in Régine Le Jan, Femmes, pouvoir et société dans le haut Moyen Age (Paris, 2001), 77; see also Pauline Stafford, 'Powerful Women in the Early Middle Ages: Queens and Abbesses', in Peter Linehan and Janet L. Nelson (eds.), The Medieval World (London, 2001), 404. 
57 These are the only five I have been able to identify with confidence from the whole Carolingian period, using Werner, 'Nachkommen' as a starting point. Ageltrude, the wife of the emperor Guy, was alleged to have founded a house at Monticello in 900, but later denied it ever existed: I Diplomi di Berengario I (ed. L. Schiaparelli, Fonti per la Storia d'Italia xxxv, Rome, 1903), no. 85.

58 Die Urkunden Karls III. (ed. P. Kehr, MGH Diplomata regum Germaniae ex stirpe Karolinorum ii, Berlin, 1936-7), nos. 7, 42, 43, 96 are the key charters, along with the charter of Richgard included in this volume. On the status of Zurzach see D. Geuenich, 'Zurzach- ein frühmittelalterliche Doppelkloster?', in H. Maurer and H. Patze (eds.), Festschrift für Berent Schwineköper zu seinem siebzigsten Geburtstag (Sigmaringen, 1982).

59 For examples, see Heinrich Büttner, Geschichte des Elsaß I. Politische Geschichte des Landes von der Landnahmezeit bis zum Tod Ottos III. Und ausgewählte Beiträge zur Geschichte des Elsaß im Früh- und Hoch mittelalter (Sigmaringen, 1991), 139-41, 295-301.

60 Die Urkunden Ludwigs des Deutschen, Karlmanns und Ludwigs des Jüngeren (ed. P. Kehr, MGH Diplomata regum Germaniae ex stirpe Karolinorum i, Berlin, 1932-4), Louis the German no.67. See M. Borgolte, Geschichte der Grafschaften Alemanniens in fränkischer Zeit (Sigmaringen, 1984), 78-101, esp. 92-6.

61 D. Geuenich, 'Aus den Anfängen der Fraumünsterabtei in Zürich', in U. Brunold and L. Deplazes (eds.), Geschichte und Kultur Churrätiens. Festschrift für Pater Iso Müller OSB zu seinem 85. Geburtstag (Disentis, 1986).

62 Die Urkunden Ludwigs (ed. Kehr), no.110. Louis the German maintained a degree of direct influence over the area: no. 82 from 857 grants the church of St-Peter's in Zurich to the royal fidelis Berold.

63 Urkundenbuch der Stadt und Landschaft Zürich (eds. J. Escher and P. Schweizer, Zurich, 1888), i, no. 131 . 

confirmation of the house's privileges and properties. grants her Zurich 'sub usufructario'; see E. Fischer, 'Das Monasterium der heiligen Märtyrer Felix und Regula in Zürich', Zeitschrift für schweizerische Kirchengeschichte, liii (1959), 165-6.

66 In the meantime he seems to have taken over the running of the convent himself: the advocate Willehar presided over the dispute recorded in Urkundenbuch (eds. Escher and Schweizer), i, no.140 (876X880), explicitly on the authority of Charles. In ibid., no.130 (Dec. 876), the same man was described as Bertha's advocate. No.140 should therefore probably be dated to the interregnum between the death of Bertha and the appointment of Richgard.

68 Lothar's charter only mentions Sélestat and Ammerschwihr by name, but Bertha's charter is clear that all the properties she donates to SS Felix and Regula were given to her personally by Lothar, presumably on the same occasion. The latter document omits Ammerschwihr, but we know from the former that this was one of the estates in question. The omission was probably accidental, which would explain why it was thought necessary to concoct the subsequent forgery Die Urkunden Karls III. (ed. Kehr), no.174, which records Zurich's right to Ammerschwihr.

69

See Borgolte, 'Karl', 36-9; or Michael Borgolte, Die Grafen Alemanniens im merowingischer und karolingischer Zeit. Eine Prosopgraphie (Sigmaringen, 1986), 106-8 on his identity. 
Schnith and R. Pauler (eds.), Festschrift für Eduard Hlawitschka zum 65. Geburtstag (Kallmünz, 1993), 107, and Michael Borgolte, 'Die Geschichte der Grafengewalt im Elsaß von Dagobert I. bis Otto dem Großen', Zeitschrift für die Geschichte des Oberrheins, cxxxi (1983), 29 claim, on the basis of Lothar's charter no. 133 from 854, that Erchangar lost this property in a dispute and fell out of favour with Lothar. However, the text only says that the dispute, which was with the cell of Leberau, was resolved by the count returning a wood he had usurped, not by having Kinzheim confiscated.

71 Borgolte, 'Grafengewalt', 33. The fact that this is certainly the case for all those properties we can trace strenghtens this assumption; the following passage provides a context for this assertion.

72

Annales Bertiniani, a . 869 (eds. F. Grat, J. Vielliard, S. Clémencet and L. Levillain, Annales de SaintBertin, Paris, 1964, 168). Hincmar's annal implies that he had little choice. See Borgolte, 'Grafengewalt', 33 for this identification of the Bernard mentioned here.

73 This was not a strict contemporary distinction in any case: Janet L. Nelson, 'The Problematic in the Private', Social History, xv (1990).

74 Such as the chaplain Perihtilo and perhaps the notary Liutfred: Urkundenbuch (eds. Escher and Schweizer), i, nos.139 and 219; J. Fleckenstein, Die Hofkapelle der deutschen Könige. I. Teil: Grundlegung. Die karolingische Hofkapelle (Stuttgart, 1959), 195.

75 Eg. Urkundenbuch (eds. Escher and Schweizer), i, no.145 from 883; cf. the general comments of J. Steinmann, Die Benediktinerinnenabtei zum Fraumünster und ihr Verhältnis zur Stadt Zürich 853-1524 (St. Ottilien, 1980), 18.

76 Andlau's foundation narrative is given by Die Urkunden Karls III. (ed. Kehr), no.96. Regino, Chronicon, a. 887 (ed. F. Kurze, Reginonis abbatis chronicon cum continuatione Treverensi, MGH SRG, 
Hanover, 1890, 127) for Andlau on Richgard's lands. Her marriage was annulled at the emperor's instigation in summer 887, and Charles died in January 888.

77 These are the so-called Statutes of Andlau: A. Bruckner, Regesta Alsatiae Aevi Merovingici et Karolini 496-918. I. Quellenband (Strasbourg and Zurich, 1949), no.656. The authenticity of this text is sometimes disputed, but the general point stands either way.

78 Die Urkunden Karls III. (ed. Kehr), no.95.

79 Bruckner, Regesta, no.470.

80

Die Urkunden Lothars II. (ed. Schieffer), no.28. Theuderic II was brought up at Marlenheim: T. Zotz, 'Das Elsaß- ein Teil des Zwischenreiches?', in H.-W. Hermann and R. Schneider (eds.), Lotharingia. Eine europäische Kernlandschaft um das Jahr 1000 (Saarbrücken, 1995), 51. On the economic importance of the estate see Büttner, Geschichte, 300.

81 Thomas Zotz, 'Carolingian Tradition and Ottonian-Salian Innovation: Comparative Observations on Palatine Policy in the Empire', in Anne J. Duggan (ed.), Kings and Kingship in Medieval Europe (London, 1993), 81-4.

82 Die Urkunden Karls III. (ed. Kehr), no.41 from 881 is an analogous case in which property ordinarily used for the upkeep of the canons in Zurich (see Urkundenbuch (eds. Escher and Schweizer), i, no.37 for this information) was given to a royal fidelis, after whose death it would revert to SS Felix and Regula. Richgard's grant of the royal monastery of Étival to Andlau was expressly made at Charles's 'urging and counsel': see Richgard's charter edited by Kehr. Charles the Fat's charter no. 24 from 880 shows the king adding royal confirmation to a distribution of Andlau's properties made by Richgard. 
Die Urkunden Zwentibolds und Ludwigs des Kinds (ed. T. Schieffer, MGH Diplomata regum

Germaniae ex stirpe Karolinorum iv, Berlin, 1960), no.68; Recueil des actes de Charles III le Simple, roi de France (893-923) (ed. P. Lauer, Paris, 1949), no.125.

85 Andlau: see the interpolated charter Die Urkunden Lothars II. (ed. Schieffer), no.34; cf. Bruckner, Regesta, no.656. Zurich: Die Urkunden Karls III. (ed. Kehr), no.174, and see above, n.

Die Urkunden Konrad I., Heinrich I. und Otto I. (ed. T. Sickel, MGH Diplomata regum et imperatorem Germaniae i, Hanover, 1879-84), no.146.

87 Arguments analogous to those which follow are made in a different context by Cristina La Rocca, 'Les Cadeaux nuptiaux de la famille royale en Italie' (forthcoming). I am grateful to Professor La Rocca for sending me a copy of this article in advance of publication.

88 Odegaard, 'Engelberge'; F. Bougard, 'Engelberga', Dizionario Biografico degli Italiani, xlii (Rome, 1993); see also P. Delogu, ‘Consors regni. Un Problema carolingio’, Bullettino dell'Istituto storico Italiano per il medioevo, lxxvi (1964). She may have benefited from the more prominent position traditionally accorded to Lombard royal women.

89 Ludowici II Diplomata (ed. K. Wanner, Fonti per la storia dell'Italia medievale, Antiquitates iii, Rome, 1994), nos. 30, 40, 45, 46, 48, 49, 51, 66, 67, not including lost charters and possible forgeries. There is no compelling reason to suspect that the survival patterns of Louis's charters heavily skew this sample.

90 Recueil des actes de Louis II le Bègue, Louis III et Carloman II, rois de France (877-884) (ed. F. Grat et al, Paris, 1978), no.78; Die Urkunden Ludwigs (ed. Kehr), no.171; Die Urkunden Karlmanns (ed. Kehr), nos.5, 16, 27; Die Urkunden Karls III. (ed. Kehr), nos.22, 56, 166; Die Urkunden Arnulfs (ed. P. Kehr, MGH 
Diplomata regum Germaniae ex stirpe Karolinorum iii, Berlin, 1940), no.49; I Diplomi di Berengario (ed. Schiaparelli), no.4.

91 Andreas, Historia, c.19 (ed. G. Waitz, MGH Scriptores Rerum Langobardicarum, Hanover, 1878, 22930); Eduard Hlawitschka, Franken, Alemannen, Bayern und Burgunder in Oberitalien (774-962). Zum Verständnis der fränkischen Königsherrschaft in Italien (Freiburg, 1960), 67-9; Paolo Delogu, 'Vescovi, conti e sovrani nella crisi del regno italico (ricerche sull'aristocrazia carolingia in Italia III)', $\underline{\text { Annali della scuola }}$ speciale per archivisti e bibliotecari dell'Università di Roma, viii (1968).

$92 \quad$ Ludovici II Diplomata (ed. Wanner), no.48.

93 Suzanne F. Wemple, 'S.Salvatore/S.Giulia: a Case Study in the Endowment and Patronage of a Major Female Monastery', in J. Kirshner and S.F. Wemple (eds.), Women of the Medieval World (Oxford, 1985) is disappointing. See instead Becher, 'Frauenkloster'; La Rocca, 'Cadeaux'; and in a wider context Barbara Rosenwein, 'The Family Politics of Berengar I, King of Italy (888-924)', Speculum, lxxi (1996).

94 G.P. Bognetti, 'Brescia carolingia', in G. Treccani et al (eds.), Storia di Brescia I: Della origini alla caduta della signoria viscontea (1426) (Brescia, 1961), 455, 464; La Rocca, 'Cadeaux', demonstrates its importance to queens throughout this period.

95 On the Supponids, see Hlawitschka, Franken, 299-309.

96 Le Carte Cremonesi dei Secoli VIII-XII (ed. E. Falconi, Cremona, 1979), i, no.20. See S. Pivano, 'Il Testamento e la famiglia dell'imperatrice Angelberga', Archivio Storico Lambardo, xlix (1922), although his genealogical analysis has been superseded by that of Hlawitschka, Franken, 299-309. 
97 Ludovici II Diplomata (ed. Wanner), no.66; the testament (ed. Falconi) explicitly refers back to this charter at 51 .

$98 \quad$ La Rocca, 'La Reine', 281-2.

99 In addition to those listed above at nn.89-90, Die Urkunden Lothars I. (ed. Schieffer), nos.37, 102; Die Urkunden Lothars II. (ed. Schieffer), no.29, and cf. nos.27 and 32; Ludovici II Diplomata (ed. Wanner), no.65; Die Urkunden Ludwigs (ed. Kehr), no.157; Die Urkunden Karls III. (ed. Kehr), nos. 18, 37, 86, 165; Die Urkunden Arnulfs (ed. Kehr), nos.141, 142.

100

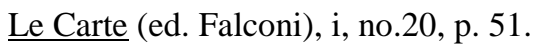

101 Ludovici II Diplomata (ed. Wanner), no.50; cf. I Diplomi di Berengario (ed. Schiaparelli), no.8.

102 Hlawitschka, Franken, 269-72; Bougard, 'Engelberga', 674.

103

C. Manaresi, I Placiti del 'regnum Italiae', 3 vols. (Rome, 1955), i, no.91; Hlawitschka, Franken, 113. His predecessor Richard may also have had Supponid family links: ibid., 252-3. S. Sisto was also built on a bloc of family property in the city: Ludovici II Diplomata (ed. Wanner), nos.67, 84. Hlawitschka, Franken, 306-7 for further evidence of Supponid solidarity. At the same time, however, the presence of Lothar II's tomb helped give Piacenza a Carolingian topography: Engelberga’s daughter was at Lothar's graveside over Christmas 880: Die Urkunden Karls III. (ed. Kehr), nos.27-8.

104 G. Porro-Lambertenghi et al (eds.), Codex Diplomaticus Langobardiae (Historiae Patriae Monumenta xiii) (Turin, 1873), nos.302, 303, 345, 403; Manaresi, Placiti, i, no.123. By 915 the nunnery belonged to Bertha, the daughter of Berengar by his Supponid wife: see Le Carte (ed. Falconi), i, no.43; I Diplomi di Berengario (ed. Schiaparelli), no.115. 
$105 \quad$ Porro-Lambertenghi et al (eds.), Codex, no. 272.

106 Conversely, widows of lower social status often found that the claims of kin (especially their late husbands') were their main threat: Nelson, 'Wary Widow', 88, 107.

107 Die Urkunden Karls III. (ed. Kehr), no.92a. P. Darmstädter, Das Reichsgut in der Lombardei und Piemont (568-1250) (Strasbourg, 1896), 231-2.

108 Die Urkunden Karls III. (ed. Kehr), no.56.

109 Ludovici II Diplomata (ed. Wanner), nos.36, 101. No. 46 shows she also had land nearby at Locarno.

$110 \quad$ Le Carte (ed. Falconi), i, no.20, p. 52.

111 In the long term, however, the claims of St-Gall appear to have triumphed over those of S. Sisto.

112 Porro-Lambertenghi et al (eds.), Codex, no. 329; Manaresi, Placiti, i, no.91. John, manager of an imperial estate in Bergamo, also seems to have been Engelberga's man: Die Urkunden Karls III. (ed. Kehr), no.86 (preserved in S. Sisto). Garibert, another representative of S. Sisto and associate of Adelbert, was also a conspicuous recipient of Charles's largesse: Die Urkunden Karls III. (ed. Kehr), nos.29, 114; PorroLambertenghi et al (eds.), Codex, no.286.

113 Upwardly-mobile aristocrats were also drawn to S. Sisto: Count Liutfrid seized a nun called Gerlinda in 879; Registrum Iohannis VIII. Papae, nos. 173, 241 (ed. E. Caspar, MGH Epistolae vii, Berlin, 1928).

114 In practice, queens often lost their dower lands once widowed: Le Jan, 'Douaires', 84.

115 In some ways, S. Giulia functioned in a similar fashion, as shown by La Rocca, 'Cadeaux'. 
116 On the status of deo sacrata, see Nelson, 'Wary Widow', 90-2. This type of widowhood was partly sanctioned by Lombard law, which was cited in the testament of the widowed empress Ageltrude (907) as an alternative point of reference to more restrictive Carolingian laws: M. Tabarrini (ed.), Cronache della città di $\underline{\text { Fermo }}$ (Documenti di Storia Italiana iv, Florence, 1870), 297-8.

117 Janet L. Nelson, 'The Siting of the Council at Frankfort: some Reflections on Family and Politics', in

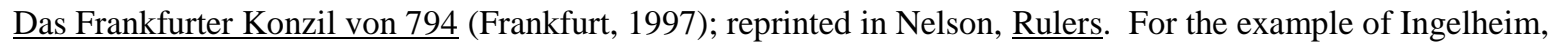
see M. Innes, 'People, Places and Power in Carolingian Society', in M. de Jong and F. Theuws (eds.), Topographies of Power in the Early Middle Ages (Leiden, Boston and Cologne, 2001), 426-7.

118 Régine Le Jan, 'Convents, Violence and Competition for Power in Seventh-Century Francia', in de Jong and Theuws (eds.), Topographies of Power, 262. Although the present argument has been very secular, the religious aspects of monastic foundations must not be forgotten.

119 Codice Diplomatico Parmense (ed. U. Benassi, Parma, 1910), no.2, pp. 101-6 (I am grateful to Dr. Francesca Tinti for help in acquiring a copy of this text); Hlawitschka, Franken, 231-3, 246-7; B. Kasten, 'Erbrechtliche Verfügungen des 8. und 9. Jahrhundert. Zugleich ein Beitrag zur Organisation und zur Schriftlichkeit bei der Verwaltung adeliger Grundherrschaften am Beispiel des Grafen Heccard aus Burgund',

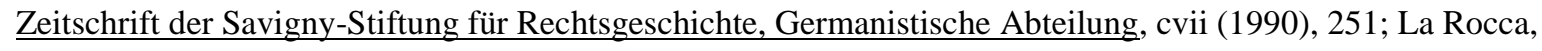
'Cadeaux'. Bruckner, Regesta, nos.532, 533, 534, 558, 645.

121 See Johannes Fried, 'Der karolingische Herrschaftsverband im 9. Jahrhundert zwischen "Kirche" und “Königshaus"”, Historische Zeitschrift, ccxxxv (1982).

122 Stafford, 'Powerful Women', 406. 

Juvigny', Studia Monastica, xxi (1979) establishes the veracity of this text. See Gallia Christiana, vol.13, cols.616-17. Political Behaviour of Secular Magnates in Francia, 829-879', University of Oxford D.Phil. thesis (1985), 194201; and Michel Parisse, 'L'abbaye de Gorze dans le contexte politique et religieux Lorrain à l'époque de Jean de Vandières (900-974)', in M. Parisse and O.G. Oexle (eds.), L'abbaye de Gorze au Xe siècle (Nancy, 1993), $56-8$.

129 Her daughter Rothild is also found active in this area in the tenth century: Werner, 'Nachkommen', 450. Similarly, Charles the Bald's first wife Ermentrude gave away her dower lands and seems to have preferred to build up her relationship with well-established ecclesiastical institutions like Chalons-sur-Marne and Corbie: see Recueil (ed. Tessier et al), nos.153, 189, 196, 212, 213, 248, 277, 278, 279. The nunnery of Jouarre, controlled by a relative of the queen, also remained a simple royal monastery, although Ermentrude's position helped it acquire relics: J. Guerout, 'Le monastère carolingienne', in Y. Chaussy et al, L'Abbaye royale Notre-Dame de Jouarre (Paris, 1961).

130 It should be stressed that these were exceptional cases, and cannot be taken as emblematic of the emancipation of aristocratic women, even lay abbesses, in this period. This is the line pursued by M. Parisse, 
'Les Femmes au monastère dans le nord de l'Allemagne du IXe au XIe siècle. Conditions sociales et religieuses', in W. Affeldt (ed.), Frauen in Spätantike und Frühmittelalter. Lebensbedingungen-LebensnormenLebensformen (Sigmaringen, 1990); cf. the commentary by J.L. Nelson in the same volume at 332.

131 Leyser, Rule, 65-6; Gerd Althoff, 'Gandersheim und Quedlinburg. Ottonische Frauenklöster als Herrschafts- und Überlieferungszentren', Frühmittelalterliche Studien, xxv (1991); M. Facinger, 'A Study of Medieval Queenship: Capetian France, 987-1237', Studies in Medieval and Renaissance History, v (1968); F.-R. Erkens, 'Die Frau als Herrscherin in ottonisch-frühsalischer Zeit', in A. von Euw and P. Schreiner (eds.), Kaiserin Theophanu. Begegnung des Ostens und Westens um die Wende der ersten Jahrtausends, 2 vols. (Cologne, 1991), ii. In general see also Duggan (ed.), Queens and Queenship; Carmi Parsons (ed.), Medieval Queenship. It should be stressed that even formalised queenship in this period remained less an impersonal office than a negotiable position: see Pauline Stafford, Queens, Concubines and Dowagers. The King's Wife in $\underline{\text { the Early Middle Ages (London, 1983), 195-6; Pauline Stafford, 'The King's Wife in Wessex, 800-1066', Past }}$ and Present, xci (1981); Stafford, 'Powerful Women', 405, 409-10.

132 Patrick Corbet, Les Saints ottoniens. Saintété dynastique, saintété royale et saintété feminine autour l'an mil (Sigmaringen, 1986), 264; Bernhardt, Itinerant Kingship. Magdeburg (937) and Selz (991) were both founded by rulers on queens' dower (fiscal) properties, rather than by queens on their family lands.

133 Gerd Althoff, 'Probleme um die Dos der Königinnen im 10. und 11. Jahrhundert', in Parisse (ed.), Veuves; Le Jan, 'Douaires', 87; Verdon, 'Recherches', 64; Stafford, Queen Emma, 127-41. La Rocca, 'Cadeaux', points to some analogous examples from Italy already in the ninth century but, as shown by Le Jan, 'Douaires', the situation was different north of the Alps. Pauline Stafford, 'Queens, Nunneries and Reforming Churchmen: Gender, Religious Status and Reform in Tenth- and Eleventh-Century England', Past and Present, clxiii (1999) highlights the room for manoeuvre available to queens given the right circumstances.

134 Verdon, 'Veuves', 198; Corbet, Les Saints ottoniens, 181-207; Corbet, 'Pro anima sua', 236-9. Cf. Stafford, Queen Emma, 252-3. 
Corbet, 'Pro anima sua', 247-50; Schulenberg, 'Women’s Monastic Communities', 287-90; Corbet, Les Saints ottoniens, 267-8. The significance of the Mass in excluding women from the church in this period, highlighted by these authors, may have been overplayed: cf. M. Innes, 'Keeping it in the Family: Women and Aristocratic Memory 700-1200', in E. van Houts (ed.), Medieval Memories: Men, Women and the Past 700$\underline{1300}$ (London, 2001).

136 As Le Jan, 'Douaires', 85-6 also argues.

137 Corbet, 'Pro anima sua', 249-50. Although exceptions could be cited: these remarks are intended to indicate only general trends. 